\title{
Effect of Maize (Zea mays L.) Plant-Type on Yield and Photosynthetic Characters of Sweet Potato (Ipomoea balatas L.) in Intercropping System
}

\author{
Yulong LUO, Xueli WU, Daobin TANG, Xun LIU, \\ Yayun LEI, Changwen LV*, Jichun WANG** \\ Southwest University, College of Agronomy and Biotechnology, Tuber Crops Research Institute, Nr. 2 Rd Tiansheng, Beibei District 400715, \\ China; 15049122397@163.com; sherrywu2013@outlook.com; tdbin741023@163.com; xunliu828@gmail.com; 501794100@qq.com; \\ lvcgwn@163.com (*correspondingauthor);wjchun@swu.edu.cn ( ${ }^{* *}$ correspondingauthor)
}

\begin{abstract}
Sweet potato/maize relay-cropping mode is considered as the main farming practices of dry land in Southwest China. Although relay-cropping would cause the reduction of fresh tuber yield, it still remained unclear that the reason was shade resulted from maize or genotype of sweet potato. The present work aims at exploring the effects of maize (Zea mays L.) planttype on photosynthetic physiology and yield of sweet potato (Ipomoea balatas L.) in relay-cropping system. Besides, three plant-types maize cultivars including compact, semi-compact and expanded type were used for relay-cropping with different sweet potato cultivars ('Yushu-2', 'Yushu-6' and 'Nanshu-88') in field. The results showed that the photosynthetically active radiation (PAR) was declined with the increase of expansion of maize plant-type, which decreased by $77.5 \%, 80.1 \%$ and $82.1 \%$ respectively. When relay-cropped with extended maize, the yield reduction rate of sweet potato was the highest (67\%). The shade-resistance of different genotype of sweet potatoes was different, and the yield reduction rate of 'Yushu-2' was the lowest (37.01\%). Through conducting correlations analysis, it showed that fresh tuber yield had significant positive correlation with Effective Quantum Yield (Y(II)) and significant negative correlation with Non Photochemical Quenching Coefficient (NPQ). In terms of 'Yushu-2', the proportion of heat dissipation was the lowest, and its light quantum efficiency was higher than others. As a result, its reduction rate of yield was lower than the other two. We suggested that compact maize cultivar relay-cropping with strong shade-resistance sweet potato cultivar should be mainly applied in practice of sweet potato.
\end{abstract}

Keywords: cultivar collocation, chlorophyll fluorescence, cultivation mode, environmental factors, photosynthetic physiology, reduction rate, shading degree

\section{Introduction}

Relay-cropping mode of sweet potato and maize is common in those areas, especially in the Southwest China. Sweet potato relay-cropping with maize represented more than half of the farming methods of dry land in Southwest China. Mixed cropping practices allowed more efficient uses of farm resources (Kolman, 1993; Tolera, 2003) and enhanced resources use ratio (Trenbath, 1986; Sivakumar, 1993; Szumigalski and Van, 2008). Besides, potential complementarity in sunlight utilization for crop production was the most important advantage of intercropping systems (Gebru, 2015). In order to make the maximized profit (Nedunchezhiyan et al., 2007) and acquire higher land equivalent ratio (LER) and yield stability (Wells et al., 2000; Skelton and Barrett, 2005), which was the ultimate aim of intercropping. Maize means shading to a great extent, though excess cloudiness encourage vegetative growth, it causes yield reduction (Nedunchezhiyan et al., 2012), especially main crop (Gliessman, 1985). Mead (1980) claimed that the benefits of multiple cropping are achieved by the simple suitability of growing crops together. To select the appropriate crop cultivars relay-cropping together is necessary to production practice. It is one of the main aims of the present research.

Light intensity made strong influence on growth and development of sweet potato (Chipungahelo et al., 2007). Though it could tolerate slight to moderate light reduction, enough strength of solar radiation was still necessary (Oswald et al., 1995). The microenvironment of plants was inevitably affected by maize and light transmission situation. Shading could decline the stomatal density (Onwuemet and Johnston, 2000). The status of ventilation and light may be different which was caused by different maize plant-type. Light condition of the mesophyll layers can affect the photosynthetic physiology (Nikolopoulos et al., 2002). Besides, net photosynthetic rate $(\mathrm{Pn})$ of crop is often influenced by 
246

environment factors such as light intensity (Kriedemann, 1968; Bowes et al., 1972; Terry, 1986; Wang et al., 2017). Intercellular $\mathrm{CO}_{2}$ concentration $(\mathrm{Ci})$ change reflects change in stomatal conductance (Caemmerer and Farquhar, 1981). Moreover, the change of transpiration rate $(\mathrm{Tr})$ could affect the leaf temperature and water potential in turn to change photosynthetic rate (Leuning, 1995; Farquhar et al., 2001; Zheng et al., 2008). Light can be used to drive photosynthesis (photochemistry), excess energy can be dissipated as heat or it can be re-emitted as light-chlorophyll fluorescence (Edossa $e t$ al., 2014). The most useful parameter measuring the photochemistry efficiency of Photosystem II was ФPSII (Genty et al., 1989), which indicated the proportion of the light used in photochemistry. Another widely used fluorescence parameter referred to 'photochemical quenching' $(\mathrm{qP})$, which given an indication of the proportion of PSII reaction centres that were open (Maxwell and Johnson, 2000). $\mathrm{Fv} / \mathrm{Fm}$ (maximum efficiency of PSII) could interrelate ФPSII and qP (Genty et al., 1989). The problem of needing to darkadapt leaves was also applied when quantifying nonphotochemical quenching (NPQ), which measured the efficiency of heat dissipation (Maxwell and Johnson, 2000). Therefore, chlorophyll fluorescence parameters provide information about the state of Photosystem II. Photosynthesis measurements was combined to obtain a full picture of the response of plants to their environment (Maxwell and Johnson, 2000).

Previous studies of intercropping mainly focused on cereallegume intercrop: maize/soybean, cowpea or pea, pea/mille or wheat, which could be summarized as effects of high canopy crop on plant growth, biomass, yield and dry matter $e t$ al., and some about the proportion of components, soil nutrient and light distribution of sweet potato in intercropping system (Midmore et al., 1988; Marchiol et al., 1992; Oswald, 1994; Oswald et al., 1995; Olasantan et al., 1996; Aladesanwa and Adigun, 2008; Wahla et al., 2009; Bedoussac and Justes, 2010; Ghanbari et al., 2010; Islam et al., 2014;). The problems were that there were rare reports about shade-tolerance of sweet potato under different maize plant-types. Numerous researches about sweet potato relay-cropping had been reported, yet failed to issue the problem of how to choose maize and sweet potato cultivar in practical production. Therefore, it was necessary to investigate what caused yield reduction of sweet potato in relaycropping system. The present work combined photosynthetic parameters and chlorophyll fluorescence, light distribution and biochemical enzymes of sweet potato. Different maize planttypes caused the reduction of sweet potato photosynthetic capacity. Expanded maize had made the greatest effect on sweet potato and NPQ and Y(II) could act as index of shadetolerance capacity of sweet potato.

\section{Materials and Methods}

\section{Plant material and cultivation conditions}

Two factors, A and B (A represented maize plant-type while B stood for sweet potato cultivar), were included in this trial, with three levels being set for each factor. Three maize planttypes, namely, the compact type 'Zhendan-958' (A1), the semicompact type 'Yudan-8' (A2) and the expanded type 'SAU1332' (A3); together with three sweet potato cultivars, namely, 'Yushu-2' (B1),'Yushu-6 (B2) and 'Nanshu-88' (B3) (with the starch contents of $23.22 \%, 26 \%$ and $16.4 \%$, respectively) were adopted in this trial.

All sweet potato (maize) cultivars were solely planted as controls (the planting space for another crop was left blank and planting density was the same as relay-cropping).

Planting method of relay-cropping - row ratio of maize to sweet potato was 2:2. Maize was planted in accordance with wide-narrow rows, with the wide row space of $123.5 \mathrm{~cm}$ and narrow row space of $40 \mathrm{~cm}$. Sweet potato was planted by ridging, with two ridges being ridged in the wide-row of maize at a ridge width and height of $40 \mathrm{~cm}$ each (Fig. 1). Planting densities of sweet potato and maize were 49,500 plants $\mathrm{hm}^{-2}$ and 52,500 plants $\mathrm{hm}^{-2}$, respectively. Maize was planted on April $1^{\text {st }}$ and harvested on July $20^{\text {th }}$; while sweet potato was planted on May $15^{\text {th }}$ and harvested on October $20^{\text {th }}$. Thus, the symbiotic period was 65 days. Fertilization and water management were the same as local practice.

All tests were carried out from March to October, 2014 in the potato crops research base of Southwest University in Xiema Town (N : 2946'3.15", E: 106 21'54.71"). Local weather conditions: annual average solar radiant quantity was $87,108 \mathrm{~kJ}$ $\mathrm{cm}^{-2}$, with an annual of 359 frost-free days. Other basic weather information during the trial was shown in Table 1 . The soil type was purple silty loam with medium fertility (higher available phosphorus content).

\section{Yield conversion}

Composite production what mean to add the dry weight of maize grain and root tuber together. Dicing root-tuber and drying to constant weight (in the constant temperature oven with $80{ }^{\circ} \mathrm{C}$ to calculate the ratio of dry matter (RDM), and the yield of sweet potato could be converted: Ys = Fresh Root Tuber $\times(1-\mathrm{RDM})$.

Land Equivalent Ratio (LER) is the most commonly used to indicate the biological efficiency and yield per unit area of land as compared to mono-cropping system (Gebru, 2015). LER can be written:

$$
\mathrm{LER}=\mathrm{Lm}+\mathrm{Ls}=\frac{\mathrm{Ym}}{\mathrm{Sm}}+\frac{\mathrm{Ys}}{\mathrm{Ss}}
$$

where ' $m$ ' was used for maize, 's' for sweet potato. 'Lm' and 'Ls' mean LER for monoculture, 'Ym' and 'Ys' mean yield in intercropping, and 'Sm' and 'Sm' mean yield in monoculture respectively.

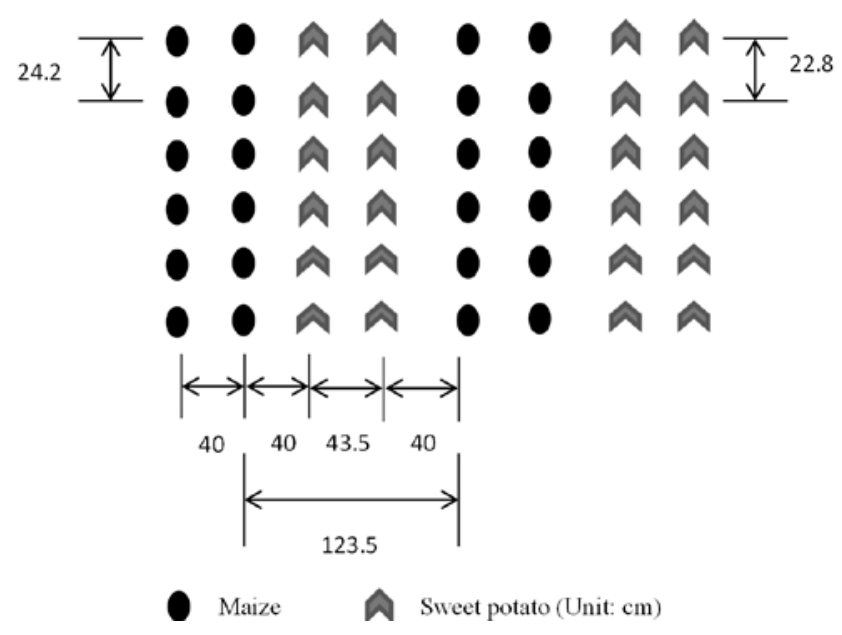

Fig. 1. Patterns in relay-cropping experiment plots 
Table 1. Basic meteorology information during the trial (from March to October)

\begin{tabular}{|c|c|c|c|c|c|c|c|c|}
\hline \multirow{2}{*}{ Item } & \multicolumn{8}{|c|}{ Month } \\
\hline & 3 & 4 & 5 & 6 & 7 & 8 & 9 & 10 \\
\hline Mean temperature $\left({ }^{\circ} \mathrm{C}\right)$ & 14.8 & 20 & 23.6 & 25.8 & 27.6 & 26.9 & 23.3 & 20.1 \\
\hline Mean rainfall $(\mathrm{mm})$ & 25 & 100 & 110 & 250 & 180 & 225 & 210 & 70 \\
\hline Mean duration of sunshine (hr) & 118 & 115 & 95 & 85 & 205 & 203 & 55 & 95 \\
\hline
\end{tabular}

Photosynthesis and chlorophyll fluorescence analyses

Such analyses were conducted at the root tuber and stem cogrowing stage (60 days after sweet potato was planted). The correlative photosynthesis rate (net photosynthetic rate, Pn), transpiration rate $(\mathrm{Tr})$, stomatal Conductance $(\mathrm{Gs})$, intercellular $\mathrm{CO}_{2}$ concentration $(\mathrm{Ci})$ were determined using the $\mathrm{Li}-6400$ portable photosynthesis system (Li-Cor Inc., Nebraska, USA) from 09:00 to 11:30 in a sunny morning. Three plants were randomly selected from each block and three leaves (top, medial and bottom leaf) were chosen from each plant for measuring photosynthetic parameters. The means of three leaves represented the finial values of $\mathrm{Pn}, \mathrm{Tr}$, Gs and Ci of the plant.

Chlorophyll fluorescence was determined on the same day (Light Curve, in the daytime with Distance Clip of 60 2035-B; Induction Curve, dark treatment for 30 min with Dark Leaf Clip of DLC-8) using Photosynthesis Yield Analyzer MINIPAM-II (Heinz Walz GmbH Inc., Germany). Five sites, which were $5 \mathrm{~cm}$ above the respective canopy of maize and sweet potato, and ground between two maize rows, two sweet potato ridges, as well as maize row and sweet potato ridge, in the intercrop system were measured by LI-191SA linear light quantum sensor (Li-Cor Inc., Nebraska, USA).

\section{Enzyme analysis}

Sweet potato leaf samples were collected from the top $4^{\text {th }}$ leaf of sweet potato 60 days after it was planted, using a $5 \mathrm{~mL}$ centrifuge tube (at the vine and root tuber growth phase). Subsequently, they were taken to lab and stored in cold storage ($40^{\circ} \mathrm{C}$ ) until used for analyses. $0.5 \mathrm{~g}$ leaf sample was placed in the grinding bowl and $4.5 \mathrm{~mL}$ of $1 / 15 \mathrm{M} \mathrm{PBS}(\mathrm{pH}=7.3)$ was added to make a slurry. $1 \mathrm{ml}$ supernate was removed from the centrifuge tube using the pipettes syringe and transferred to the Elisa plate for test by ELISA Kit.

Date analysis

All the data we had obtained were analyzed and organized by the software of Microsoft Excel. 2010, and used SPSS.21 (Statistic Package for Social Science) for analysis of variance and correlation.

\section{Results}

\section{The Fresh Tuber Yield (FTY) and Composite Production}

Same FTY change tendency could be seen in diverse planttypes of maize in the intercrop system (Fig. 2 B). Sweet potato and maize cultivars in the intercrop system, as well as the combined action of A (maize) and B (sweet potato) had notably affected the yield of fresh tuber $(\mathrm{P}<0.05)$. Intercrop had resulted in reduction in production, which followed the treatment order of $\mathrm{A} 3 \mathrm{~B} 1<\mathrm{A} 3 \mathrm{~B} 2<\mathrm{A} 2 \mathrm{~B} 2<\mathrm{A} 2 \mathrm{~B} 1<\mathrm{A} 1 \mathrm{~B} 1<$ $\mathrm{A} 3 \mathrm{~B} 3<\mathrm{A} 2 \mathrm{~B} 3<\mathrm{A} 1 \mathrm{~B} 2<\mathrm{A} 1 \mathrm{~B} 3$, with difference being statistically significant $(\mathrm{P} \leq 0.05)$. Relay-cropping had reduced fresh tuber by $37.01-54.21 \%$ for B1, 48.33-67.24\% for B2 and $55.64-66.33 \%$ for $\mathrm{B} 3$. Highest yield reduction rate $(67 \%)$ of sweet potato could be achieved in the case of relay-cropping with extended maize. In a word, different genotypes of sweet

potatoes were associated with different degrees of shaderesistance, and 'Yushu-2' had the lowest yield reduction rate (37.01\%).

It was not the same case when the yield of maize was taken into combined consideration to judge the overall benefits (Fig. $2 \mathrm{~A}$ and Table 2). The composite production followed the order below: $\mathrm{A} 1 \mathrm{~B} 2>\mathrm{A} 1 \mathrm{~B} 3>\mathrm{A} 2 \mathrm{~B} 2>\mathrm{A} 1 \mathrm{~B} 1>\mathrm{A} 3 \mathrm{~B} 2>\mathrm{A} 2 \mathrm{~B} 3$ $>\mathrm{A} 2 \mathrm{~B} 1>\mathrm{A} 3 \mathrm{~B} 3>\mathrm{A} 3 \mathrm{~B} 1$. The maximum composite production was $15,894.17 \mathrm{Kg} \mathrm{hm}^{-2}$, which was higher than that of monoculture of two crops. Besides, composite production in A1 intercropping with three sweet potato cultivars was significantly higher than the others. Tests of Between-Subjects Effects (Table 2) suggested that $\mathrm{A}(\mathrm{F}=32.647)$ had more effect on composite production than $\mathrm{B}(\mathrm{F}=12.853)$, but difference in reciprocal action between $A$ and $B$ was not significant.

A

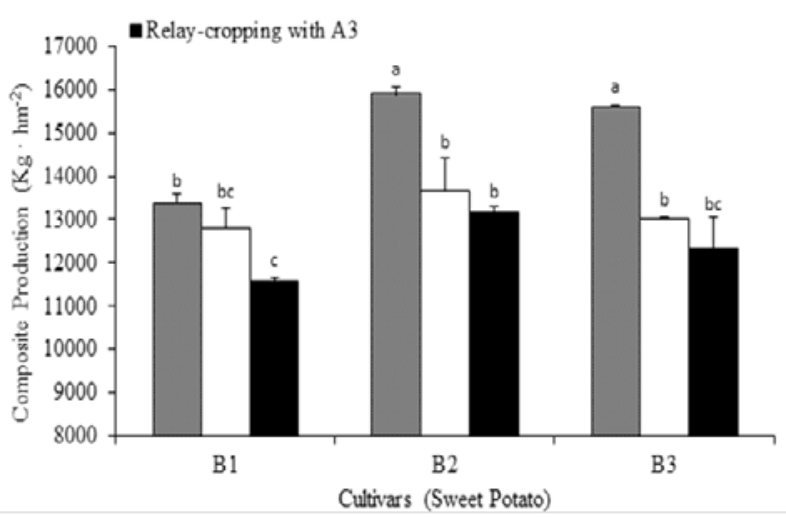

$\mathrm{B}$

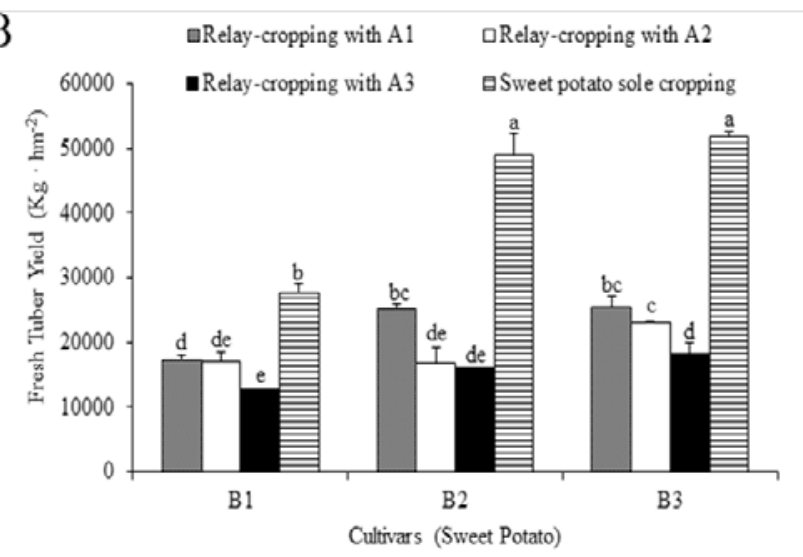

Fig. 2. The effect of maize plant-type on composite production (A, dry weight of maize grain and root tuber) and sweet potato fresh tuber yield (B). Note: A1, 'Zhendan-958'; A2, 'Yudan-8'; A3, 'SAU-1332'. B1, 'Yushu-2'; B2, 'Yushu-6'; 'Nanshu-88'; Error bars represented \pm SE (standard errors) of 3 replicates; Different letters on each bar show significant difference at $p \leq$ 0.05 by Duncan's multiple range tests; Square column in histogram meant different sweet potato cultivars relay-cropped with different plant-types of maize (legend item) 
Table 2. Tests of Between-Subjects Effects of the effect of sweet potato cultivar, maize plant-type and their interaction on composite production

\begin{tabular}{|c|c|c|c|c|c|}
\hline \multicolumn{6}{|c|}{ Dependent Variable: Composite Production } \\
\hline Source & $\begin{array}{c}\text { Type III } \\
\text { Sum of Squares }\end{array}$ & df & Mean Square & $\mathrm{F}$ & Sig \\
\hline $\mathrm{A}$ & 31747081.8 & 2 & 15873540.9 & 32.674 & $* *$ \\
\hline B & 12489005.7 & 2 & 6244502.8 & 12.853 & $* *$ \\
\hline$A * B$ & 3600474.0 & 4 & 900118.5 & 1.853 & ns \\
\hline
\end{tabular}

R Squared $=0.845$ (Adjusted R Squared $=0.777$ )

Note: ${ }^{* *}$ Significantly different at the 0.01 probability levels; ns, not significant at $\mathrm{p} \leq 0.05$; $\mathrm{A}$ and $\mathrm{B}$ meant maize and sweet potato cultivar respectively. $\mathrm{A}^{*} \mathrm{~B}$ meant $\mathrm{A}$ and B interactions.

\section{Land Equivalent Ratio (LER)}

The LERs of relay-cropping were higher than those of monoculture (Table 3). The LERs of B2 and B3 monocultures showed no significant differences when relay-cropping with A2 and $A 3$, respectively, which displayed distinct difference when relay-cropping with A1. LERs of B1 and B2 cultivars in different relay-cropping systems displayed notable differences when relay-cropping with each other $(P \leq 0.05)$. There was almost no significant difference in maize cultivars intercropping with sweet potato, except for $\mathrm{A} 1$ and $\mathrm{A} 2$ intercropping with $\mathrm{B} 3$. Both sweet potato cultivars and maize cultivars exert remarkable effects on the total LER value, and the differences were statistically significant $(\mathrm{P} \leq 0.05)$. Moreover, the maximum total LER value was achieved in A2B1 (1.835). Thus, it could be seen that it was more suitable for relay-copping compact maize cultivar with sweet potato. 'Yushu-2' (B1) had higher shade-resistance than the other two cultivars, which made it unsuitable for relay-cropping.

\section{Photosynthetic Parameters in Response to Intercropping \\ Net Photosynthetic Rate}

Intercropping had resulted in reduced net photosynthetic rate $(\mathrm{Pn})$ (Fig. $3 \mathrm{~B}$ ), with the difference being statistically significant $(\mathrm{P} \leq 0.05)$. B1 relay-cropping with different maize cultivars displayed the highest reduction of $28.13 \%$ when compared to that of monoculture, which was $30.37 \%$ for B2 and $40.61 \%$ for $\mathrm{B} 3$. The decreasing amplitude of relaycropping followed the order below: A3 > A2 > A1 (A3, A2 and $\mathrm{A} 1$ represented the expanded, semi-compact and compact maize plant-types, respectively). In another word, the more shading area was associated with the lower Pn value. For the same sweet potato cultivar, A2 and A1 had no significant difference, but difference between $\mathrm{A} 1$ and $\mathrm{A} 3$ was significant $(P \leq 0.05)$. All sweet potato cultivars relay-cropping with A1 had higher Pn values, with A1B2 being the collocation of highest $P n$ value.

\section{Transpiration Rate}

The trend of transpiration rate ( $\mathrm{Tr}$ ) (Fig. 3B) was similar, and monoculture had higher $T r$ values, which had reached the significant level. $\operatorname{Tr}$ values reduced accompanied by the extension of maize plant-type (A1 to A3). Difference in shade degree as well as the factor of sweet potato cultivar had apparently influenced the $\operatorname{Tr}$ value $(\mathrm{P} \leq 0.05)$. Correlation analysis indicated that there were no significant differences $(\mathrm{P}$ $=0.083>0.05)$ in Pn and Tr in this experiment.

\section{Intercellular $\mathrm{CO}_{2}$ Concentration $(\mathrm{Ci})$}

There were significant differences $(\mathrm{P} \leq 0.05)$ among B1, B2 and $\mathrm{B} 3$ for monoculture (Fig. $3 \mathrm{~A}$ ). All relay-cropping collocations had distinctly higher $\mathrm{Ci}$ values than their corresponding monoculture modes. Results of analysis of variance suggested that, compared with the maize plant-types, sweet potato cultivar had greater influence on $\mathrm{Ci}$ within relaycropping system. A3 relay-cropping with sweet potato could lead to higher $\mathrm{Ci}$ value than the others. $\mathrm{Ci}$ values of all collocations followed the order of $\mathrm{A} 3 \mathrm{~B} 1>\mathrm{A} 2 \mathrm{~B} 1>\mathrm{A} 1 \mathrm{~B} 1$, which was similar to that of the other two sweet potato cultivars).

\section{Stomatal Conductance (Gs)}

Gs displayed the same variation trend with $\mathrm{Tr}$, but was opposite to Ci (Fig. $3 \mathrm{C}$ ). Cultivar (sweet potato and maize, $\mathrm{P}$ $<0.01)$ and interaction of cultivar $(\mathrm{P}=0.02)$ had conspicuous

Table 3. Comparison of LER (Land Equivalent Ratio) value between different relay-cropping collocations and sweet potato sole cropping

\begin{tabular}{|c|c|c|}
\hline \multirow{2}{*}{ Treatments } & \multicolumn{2}{|c|}{ LER } \\
\hline & Sweet potato (sole) & Total LER \\
\hline A1B1 & $0.611 \pm 0.023 \mathrm{ab}$ & $1.747 \pm 0.071 \mathrm{ab}$ \\
\hline A1B2 & $0.355 \pm 0.074 \mathrm{~d}$ & $1.430 \pm 0.091 \mathrm{~cd}$ \\
\hline A1B3 & $0.634 \pm 0.016 a$ & $1.562 \pm 0.047 \mathrm{bcd}$ \\
\hline $\mathrm{A} 2 \mathrm{~B} 1$ & $0.631 \pm 0.006 \mathrm{a}$ & $1.835 \pm 0.034 \mathrm{a}$ \\
\hline $\mathrm{A} 2 \mathrm{~B} 2$ & $0.521 \pm 0.024 b c$ & $1.641 \pm 0.089 \mathrm{abc}$ \\
\hline $\mathrm{A} 2 \mathrm{~B} 3$ & $0.499 \pm 0.035 c$ & $1.627 \pm 0.066 \mathrm{abc}$ \\
\hline $\mathrm{A} 3 \mathrm{~B} 1$ & $0.460 \pm 0.018 c$ & $1.621 \pm 0.005 \mathrm{abc}$ \\
\hline A3B2 & $0.331 \pm 0.02 \mathrm{~d}$ & $1.419 \pm 0.025 \mathrm{~cd}$ \\
\hline A3B3 & $0.352 \pm 0.025 \mathrm{~d}$ & $1.350 \pm 0.12 \mathrm{~d}$ \\
\hline \multicolumn{3}{|l|}{ Significant Level } \\
\hline A (Maize) & & * \\
\hline B (Sweet Potato) & & $*$ \\
\hline $\mathrm{A}^{*} \mathrm{~B}$ (interaction) & & ns \\
\hline C.V. \% & 25.88 & 11.57 \\
\hline
\end{tabular}

Note: Different lowercase in each column showed significant difference at $\mathrm{p} \leq 0.05\left(^{*}\right)$ by Duncan's multiple range tests's multiple range tests; ns, no significant at $\mathrm{p} \leq$ 0.05 . 'C.V.\%', coefficient of variation; 'Value \pm SE', average of 3 replicates \pm SE (standard errors); A, maize plant-type factor; B, sweet potato cultivar factor; $A^{*} B$, A and B interactions 
effect on Gs. The cultivar of extended maize led to lower Gs value in sweet potato. Influence of maize plant-type on Gs followed the order of A1 > A2 > A3. For sweet potato, B1 and $\mathrm{B} 2$ displayed no significant difference in Gs $(\mathrm{P}>0.05)$, but $\mathrm{B} 1$ and $\mathrm{B} 2$ had significantly greater $\mathrm{Gs}$ than that of $\mathrm{B} 3(\mathrm{P} \leq 0.05)$.

Therefore, relay-cropping decreased the net photosynthetic rate, stomatal conductance and intercellular $\mathrm{CO}_{2}$ concentration, but different maize plant-types revealed various degrees of influence. Alternatively speaking, different sweet potato cultivars had different degrees of reduction. $\mathrm{Pn}$ in $\mathrm{A} 1$, $\mathrm{A} 2$ and $\mathrm{A} 3$ relay-cropping systems had decreased by 12.34 $18.17 \%, 19.74-23.62 \%$ and $28.31-40.41 \%$, respectively, while Gs had reduced by $3.10-8.27 \%, 8.93-19.65 \%$ and 10.01 $33.86 \%$, respectively, an $\operatorname{Tr}$ had lowered by $22.68-28.08 \%$, $33.61-45.39 \%$ and $41.54-56.77 \%$, respectively, comparing with their corresponding monocultures. In the relay-cropping system, B1 showed higher shade-resistance than B2 and B3; meanwhile, the reduction rate in $\mathrm{Pn}, \mathrm{Gs}$ and $\mathrm{Tr}$ of $\mathrm{B} 1$ were lower than those of $\mathrm{B} 2$ and $\mathrm{B} 3$.

\section{Chlorophyll Fluorescence Parameters}

Effective Photochemical Quantum Yields of PSII (Y(II))

The Y(II) values (Table 4) of sweet potato in relaycropping system were significantly $15.37-42.50 \%$ lower $(\mathrm{P} \leq$ $0.05)$ than their monocultures. B1 relay-cropping with three kinds of maize cultivars had better behaviors with the minimum decreasing amplitudes. Relay-cropping could reduce $\mathrm{Y}$ (II) level as maize plant-types changed (A1 to A3), but the difference in variety was not significant, which might be related to the different degrees of shade-tolerance.

\section{Coefficients of Photochemical Fluorescence Quenching (qP)}

Relay-cropping could also affect the proportion of open PSII reaction centers. The $\mathrm{qP}$ values (Table 4) of single cropping of sweet potato were higher than those of relaycropping for themselves. The maize plant-types could not significantly affect the $\mathrm{qP}$ values; however, it declined with the extension of plant-types. The maximum qP value could be seen in A1B3 in the relay-cropping system (namely, 'Zhendan-958' relay-cropping with 'Nanshu-88').

Maximum Photochemical Quantum Yields of PSII (Fv/Fm)

As was shown in Table 4, Fv/Fm value of sweet potato monoculture was higher than its corresponding relay-cropping. Results of analysis of variance had suggested that the difference between A1B2 and A3B2 had reached significant level. Compared with monoculture, the relay-cropping only resulted in $2.03-4.29 \%$ decline in $\mathrm{Fv} / \mathrm{Fm}$. Fv/Fm value of A1B2 was higher than that of the other relay-cropping systems. Differences in relay-cropping among the three sweet potato
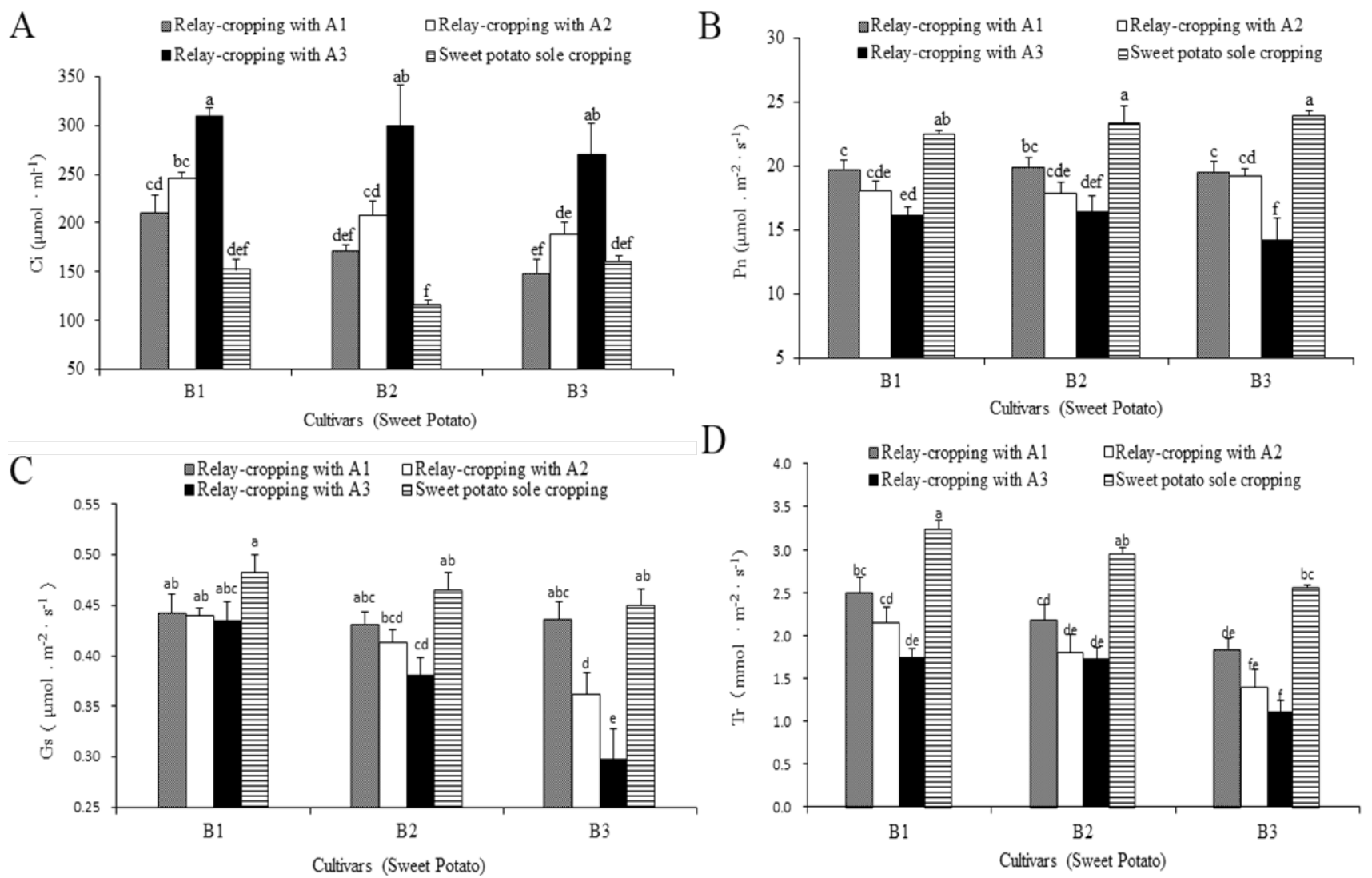

Fig. 3. Comparison of intercellular $\mathrm{CO}_{2}$ concentration $(\mathrm{Ci}, \mathrm{A})$, net photosynthetic rate (Pn, B), stomatal conductance(Gs, C) and transpiration rate $(\mathrm{Tr}, \mathrm{D})$ of sweet potato relay-cropping with different plant-type maize cultivars and sweet potato sole cropping. Note: A1, 'Zhendan-958'; A2, 'Yudan-8'; A3, 'SAU-1332'. B1, 'Yushu-2'; B2, 'Yushu-6'; 'Nanshu-88'; Error bars represented \pm SE (standard errors) of 5 replicates; Different letters on each bar showed significant difference at $p \leq 0.05$ by Duncan's multiple range tests; Square column in histogram meant different sweet potato cultivar relay-cropped with different plant-types of maize (legend item) 
250

cultivars were not significant, but it showed preferably as a whole when they were collected with B1 (compact plant-type cultivar of maize).

\section{Parameters of Non-Photochemical Quenching (NPQ)}

Thermal dissipation of sweet potato photosynthetical system could be reflected by NPQ value. The trend of influence of relay-cropping on NPQ value (Table 4) was contrary to that of $\mathrm{Fv} / \mathrm{Fm}$. Relay-cropping could elevate NPQ value compared with the monoculture, which increased accompanied by the extension of maize plant-type (A1 to A3). In addition, both the maize plant-type and sweet potato cultivar could markedly affect the change of NPQ $(P \leq 0.01)$. Compared with the monoculture mode, the change range of NPQ was the lowest in B1 among the three sweet potato cultivars when it relay-cropped with all maize plant-types.

\section{Relative Electron Transfer Rate (ETR)}

As could be seen in Table 4, differences among different treatments were not significant. But sweet potato cultivar $(\mathrm{F}=$ 2.023) had greater effect on ETR than that of maize plant-type $(\mathrm{F}=0.717)$. ETR of each sweet potato variety had declined with the extension from A1 to A3. The maximum ETR appeared in $\mathrm{A} 3 \mathrm{~B} 3$ and $\mathrm{B} 3$ in the intercropping and monoculture systems, respectively. There was no significant difference between relay-cropping and sole cropping.

Fluorescence parameters showed that sweet potato in relaycropping would subject to low light stress. B1 showed higher photon capture efficiency than B2 and B3, because its reduction rate of $\mathrm{Fv} / \mathrm{Fm}$ (average value was $25.57 \%$ ) was lowest than sole cropping. and its heat dissipation ratio increased by 6.96\% which lower than B2 (46.01\%) and B3 (8.84\%).

\section{Photosynthetically Active Radiation (PAR)}

As was shown in Fig.4, great difference could be seen among different sites in the intercropping system, especially between maize canopies and the underneath sweet potato canopies. There were no significant differences in their PAR of maize canopy, as well as in sweet potato row interval (Fig. 4). It was worth noting that sweet potato canopies were affected by shade of maize. In addition, different plant-types had resulted in various degrees of differences in PAR $(\mathrm{A} 1>\mathrm{A} 2>\mathrm{A} 3)$, all of which reached significant level. The luminousness of different maize canopies followed the order of A1 $(22.46 \%)>\mathrm{A} 2$ $(19.88 \%)>$ A3 (17.95\%).

\section{RuBisCO and SPS Activity \\ $\mathrm{RuBis} C O$}

Activity of key enzyme of photosynthesis RuBisCO had diminished (Fig. 5 B) as a result of relay-cropping; meanwhile, it was distinctly affected by maize plant-type $(\mathrm{P} \leq 0.05)$. But the effect of sweet potato cultivar (namely, genotype difference) was not significant $(P=0.263>0.05)$. Significant differences could be seen among $\mathrm{A} 1, \mathrm{~A} 2$ and $\mathrm{A} 3$ relay-cropping with $\mathrm{B} 1$, B2 but not B3, for the same sweet potato. For sweet potato monoculture, B2 (high starch cultivar) had the highest enzyme activity. However, it had the most notable decline (4.13\% to $6.96 \%$ ) among the three kinds of sweet potatoes in relaycropping system. A1B1 had the highest RuBisCO activity in the relay-cropping mode, which was conducive to fix photosynthetic product.

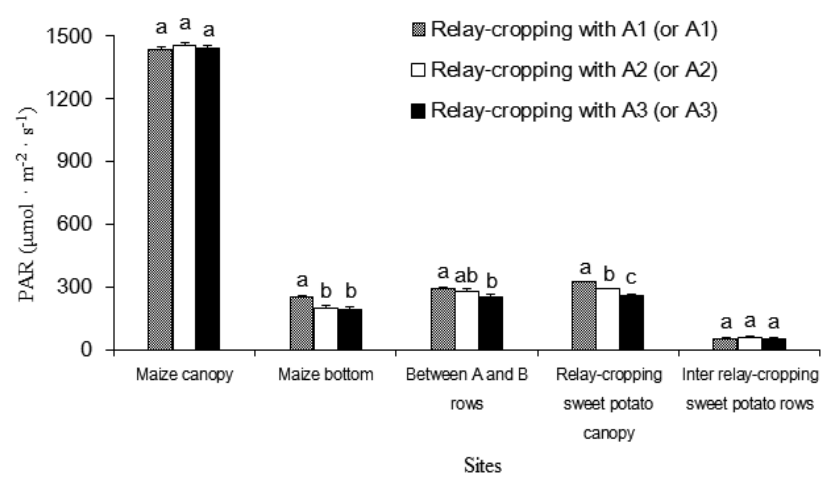

Fig. 4. The effect of plant-type on PAR (photosynthetically active radiation) in different sites between maize and sweet potato canopy. Note: All sites were measured in relay-cropping system. Error bars represented \pm SE (standard errors) of 5 replicates; Different letters on each bar show significant difference at $\mathrm{p} \leq 0.05$ by Duncan's multiple range tests; A1, 'Zhendan-958'; A2, 'Yudan-8'; A3, 'SAU-1332'

Table 4. The comparison of fluorescence parameters of different treatments

\begin{tabular}{|c|c|c|c|c|c|}
\hline Treatment & $\mathrm{Fv} / \mathrm{Fm}$ & $\mathrm{Y}(\mathrm{II})$ & $\mathrm{qP}$ & NPQ & ETR \\
\hline A1B1 & $0.847 \pm 0.002 b$ & $0.413 \pm 0.004 b$ & $0.581 \pm 0.004 c$ & $0.902 \pm 0.002 \mathrm{~cd}$ & $15.7 \pm 0.8 \mathrm{a}$ \\
\hline A1B2 & $0.849 \pm 0.004 b$ & $0.400 \pm 0.005 b c$ & $0.599 \pm 0.009 b c$ & $0.974 \pm 0.027 b c$ & $16.7 \pm 0.3 \mathrm{a}$ \\
\hline A1B3 & $0.845 \pm 0.005 b c$ & $0.378 \pm 0.005 b c d$ & $0.602 \pm 0.006 b c$ & $0.862 \pm 0.025 \mathrm{de}$ & $17.2 \pm 0.6 a$ \\
\hline $\mathrm{A} 2 \mathrm{~B} 1$ & $0.846 \pm 0.006 b$ & $0.361 \pm 0.019 \mathrm{bcde}$ & $0.577 \pm 0.007 c$ & $1.034 \pm 0.046 b$ & $15.3 \pm 1.7 \mathrm{a}$ \\
\hline $\mathrm{A} 2 \mathrm{~B} 2$ & $0.844 \pm 0.002 b c$ & $0.326 \pm 0.007 \mathrm{de}$ & $0.595 \pm 0.022 c$ & $1.017 \pm 0.051 b$ & $16.3 \pm 0.4 a$ \\
\hline A2B3 & $0.843 \pm 0.003 b c$ & $0.355 \pm 0.023 \mathrm{cde}$ & $0.596 \pm 0.004 b c$ & $1.014 \pm 0.032 b$ & $16.3 \pm 0.8 \mathrm{a}$ \\
\hline $\mathrm{A} 3 \mathrm{~B} 1$ & $0.837 \pm 0.002 b c$ & $0.323 \pm 0.009 \mathrm{e}$ & $0.558 \pm 0.072 c$ & $1.190 \pm 0.041 \mathrm{a}$ & $14.7 \pm 0.9 \mathrm{a}$ \\
\hline A3B2 & $0.832 \pm 0.002 c$ & $0.311 \pm 0.007 \mathrm{e}$ & $0.578 \pm 0.005 c$ & $1.040 \pm 0.015 b$ & $15.4 \pm 1.1 \mathrm{a}$ \\
\hline A3B3 & $0.837 \pm 0.004 b c$ & $0.310 \pm 0.021 \mathrm{e}$ & $0.577 \pm 0.02 c$ & $1.047 \pm 0.011 b$ & $15.6 \pm 1.7 \mathrm{a}$ \\
\hline CKB1 & $0.865 \pm 0.006 \mathrm{a}$ & $0.486 \pm 0.02 \mathrm{a}$ & $0.685 \pm 0.017 a$ & $0.844 \pm 0.013 \mathrm{de}$ & $16.2 \pm 0.6 \mathrm{a}$ \\
\hline CKB2 & $0.869 \pm 0.007 \mathrm{a}$ & $0.494 \pm 0.031 \mathrm{a}$ & $0.720 \pm 0.015 a$ & $0.667 \pm 0.021 \mathrm{f}$ & $17.1 \pm 0.2 \mathrm{a}$ \\
\hline CKB3 & $0.868 \pm 0.001 \mathrm{a}$ & $0.465 \pm 0.022 \mathrm{a}$ & $0.674 \pm 0.029 \mathrm{ab}$ & $0.792 \pm 0.025 \mathrm{e}$ & $17.3 \pm 0.4 a$ \\
\hline \multicolumn{6}{|l|}{ Significant Level } \\
\hline A (maize) & ns & ns & ns & ** & $\mathrm{ns}$ \\
\hline B (sweet potato) & ** & $* *$ & ns & ** & ns \\
\hline $\mathrm{A}^{*} \mathrm{~B}$ & $\mathrm{~ns}$ & ns & ns & ns & $\mathrm{ns}$ \\
\hline C.V. \% & 1.58 & 18.05 & 6.97 & 15.06 & 9.6 \\
\hline
\end{tabular}

Note: A1, 'Zhendan-958'; A2, 'Yudan-8'; A3, 'SAU-1332'. B1, 'Yushu-2'; B2, 'Yushu-6; 'Nanshu-88'; Error bars represented \pm SE(standard errors) of 3 replicates: Different letters on each bar showed significant difference at $\mathrm{p} \leq 0.05$ by Duncan's multiple range tests; 'Value \pm SE', average of 3 replicates \pm SE (standard errors); '**' represent difference at $\mathrm{p} \leq 0.01\left({ }^{* *}\right)$ by Duncan's multiple range tests's multiple range tests; 'C.V.\%', coefficient of variation; ns, not significant at $\mathrm{p} \leq 0.05$; A, maize planttype factor; B, sweet potato cultivar factor; $\mathrm{A}^{*} \mathrm{~B}$ represent $\mathrm{A}$ and $\mathrm{B}$ interactions. 
Sucrose Phosphate Synthase (SPS)

SPS activity under different treatments showed different trend (Fig. 5 A) with that of $\mathrm{RuBisCO}$. Relay-cropping resulted in increased SPS activity in sweet potato leaves, which could also increase with extension of maize plant-type. From the point of view of monoculture, B3 had the highest SPS activity over the others. Moreover, B3 also had higher SPS activity than the other cultivars in relay-cropping with the same maize plant-type. Both maize plant-type and sweet potato cultivar had greatly influenced SPS activity. There were significant differences among sweet potato cultivars $(\mathrm{P} \leq 0.05)$.

There were no significant differences in RuBisco activity among three sweet potato cultivars in their corresponding monocultures. But B1 in the relay-cropping system showed

A
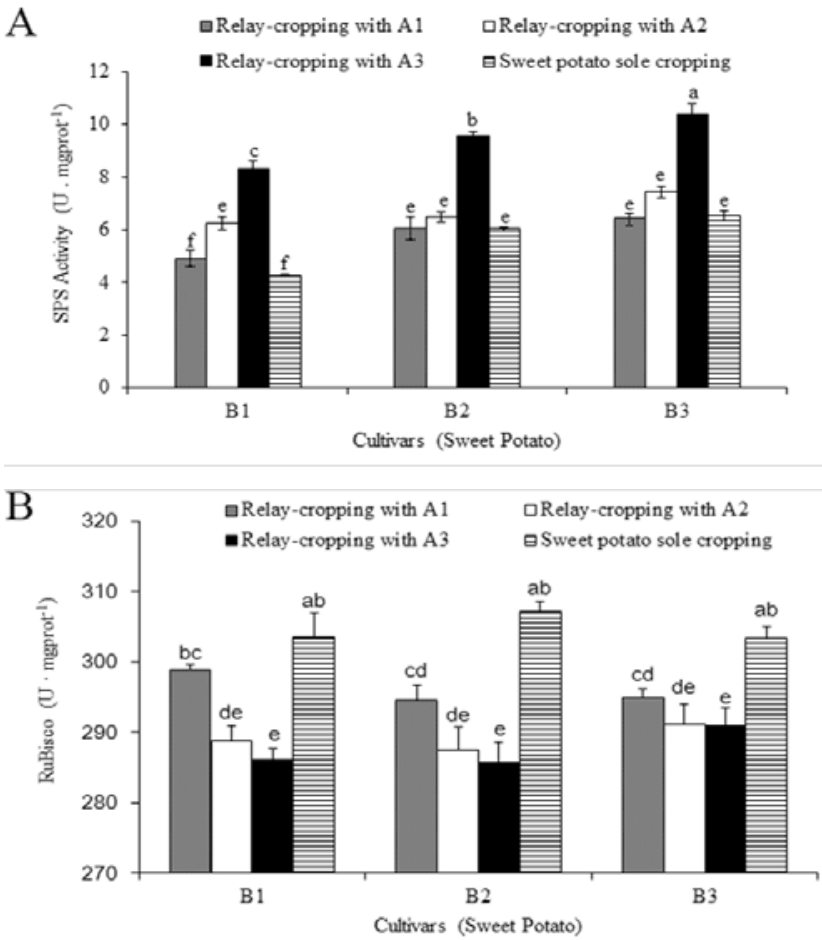

Fig. 5. Comparison of the SPS (A) and RuBisCO (B) activity in different treatments. Note: A1, 'Zhendan-958'; A2, 'Yudan-8'; A3, 'SAU-1332'. B1, 'Yushu-2'; B2, 'Yushu-6'; 'Nanshu-88'; Error bars represented \pm SE (standard errors) of 4 replicates; Different letters on each bar show significant difference at $\mathrm{p} \leq$ 0.05 by Duncan's multiple range tests; Square column in histogram meant different sweet potato cultivars relay-cropping with different plant-types of maize (legend item) advantage over others in carbon dioxide fixation. In addition, $\mathrm{B} 1$ also had the highest reduction rate of SPS activity; thus, B1 was to the disadvantage in term of final sucrose formation.

\section{Discussion}

Sweet potato is grown under different shade conditions for about two months, and the photosynthetic and chlorophyll fluorescence responses in different maize plant-types (light conditions) are evaluated. The results show that the yield of sweet potato is affected by maize, which also displays genotype difference.

\section{Correlation analysis}

As is shown in Table 5, all photosynthesis related parameters (Tr, r=0.2; Pn, r=0.24; Gs, r=0.02) are positively correlated with yield, but the differences are not statistically significant $(\mathrm{P}>0.05)$. $\mathrm{Y}(\mathrm{II})$ shows remarkably positive correlation with fresh tuber yield $(\mathrm{P}<0.01)$, but NPQ is distinctly negatively correlated with fresh tuber yield $(\mathrm{P}<0.01)$. The correlation coefficients of other chlorophyll fluorescence parameters (qP, r=0.37; Fv/Fm, r=0.35; ETR, r=0.33) are all at low level. Starch is mainly accumulated in root of sweet potato, and sucrose content is generally negatively correlated with starch accumulation. This is confirmed by results of this study (SPS with yield, $r=-0.29$ ). RuBisco participates in tricarboxylic acid cycle, which is positively correlated with all photosynthesis related parameters except for $\mathrm{Ci}$.

\section{Production efficiency analysis}

Results of numerous studies about relay-cropping (or intercropping) systems, such as maize/climbing bean (Tolera, 2003), maize/cowpea (Ghanbari et al., 2010), sweet potato/okra (Njoku et al., 2007), sweet potato/maize (Islam et al., 2014), all indicate that such system has a high yield potential for the composite production except for the sole root tuber yield. Our results are similar to those from Oswald et al. (1994), which show that shade level has the greatest influence on tuber formation and finally the tuber yield. The reason for the presence of different yield behaviours may be related to the difference in cultivar tolerance (Oswald et al., 1995).

The composite production of relay-cropping is higher than their monocultures respectively, despite that relay-cropping has caused decreases in fresh tuber yield. The yield of 'Yushu-2' is remarkably lower than that of 'Yushu-6' and 'Nanshu-88' in single cropping, but the shade-tolerance of 'Yushu-2' is stronger than the other two in the relay-cropping system. As a result, 'Yushu-2' is more suitable for relay-cropping considering the

Table 5. Correlations analysis (Pearson Correlation) of all indicators and fresh tuber yield

\begin{tabular}{|c|c|c|c|c|c|c|c|c|c|c|c|}
\hline & Yield & $\mathrm{Pn}$ & $\mathrm{Tr}$ & Gs & $\mathrm{Ci}$ & $\mathrm{Fv} / \mathrm{Fm}$ & $\mathrm{Y}(\mathrm{II})$ & $\mathrm{qP}$ & NPQ & ETR & SPS \\
\hline $\mathrm{Pn}$ & 0.20 & & & & & & & & & & \\
\hline $\operatorname{Tr}$ & 0.24 & $0.445^{* *}$ & & & & & & & & & \\
\hline Gs & 0.02 & 0.25 & $0.66^{* *}$ & & & & & & & & \\
\hline $\mathrm{Ci}$ & -0.08 & $-0.579^{* *}$ & -0.10 & 0.10 & & & & & & & \\
\hline $\mathrm{Fv} / \mathrm{Fm}$ & 0.35 & 0.12 & 0.23 & 0.07 & -0.16 & & & & & & \\
\hline $\mathrm{Y}(\mathrm{II})$ & $0.62^{* *}$ & $0.561^{* *}$ & $0.41^{*}$ & 0.16 & -0.22 & $0.41^{*}$ & & & & & \\
\hline $\mathrm{qP}$ & 0.37 & 0.20 & 0.34 & -0.01 & -0.13 & 0.12 & 0.17 & & & & \\
\hline NPQ & $-0.65^{* *}$ & -0.31 & -0.32 & -0.17 & 0.29 & $-.39^{*}$ & $-0.62^{* *}$ & -0.10 & & & \\
\hline ETR & 0.33 & 0.17 & 0.35 & 0.02 & -0.21 & 0.03 & $0.39^{*}$ & 0.01 & -0.26 & & \\
\hline SPS & -0.29 & -0.23 & $-0.59^{* *}$ & $-0.57^{* *}$ & 0.26 & $-0.670^{* *}$ & $-.607^{* *}$ & -0.16 & $0.50^{* *}$ & -0.13 & \\
\hline RuBisco & 0.15 & $0.38^{*}$ & 0.32 & 0.21 & -0.09 & 0.37 & $0.57^{* *}$ & 0.19 & -0.36 & 0.28 & $-0.55^{* *}$ \\
\hline
\end{tabular}

Note: ${ }^{* *}$ Correlation is significant at the 0.01 level (2-tailed). ${ }^{*}$ Correlation is significant at the 0.05 level (2-tailed). 
252

genotype of sweet potato. Advantage of relay-cropping over single cropping can be reflected by composite production, which can also be attributed to the role of maize. Although relay-cropping has resulted in reduced yield of sweet potato, it is beneficial to the growth of maize. Sweet potato is an appropriate crop for use as live mulch, which can be effectively exploited for weed suppression, thus improving the growth responses in maize (Aladesanwa and Adigun, 2008). Similar to sorghum/soybean, high-position plant sorghum acquires higher grain yield (Ghosh et al., 2004).

\section{Interception oflight}

The taller component can intercept the major share of light; as a result, growth rates of the two components are proportional to the quantities of the photosynthetically active radiation (PAR) they intercept. Fig. 4 has showed that maize canopy has decreased the light reduction (LR) by $77.53 \%$ to 82.05\%. Less PAR will lead to fewer 'sources' of light for sweet potato under the condition of relay-cropping. Thus, the physiological process of sweet potato is affected by weak light, which is unfavourable for the formation of root tuber compared with that under full sunlight. On the one hand, the formation of root tuber is almost completely suppressed when the light has reduced over 73\% (Roberts et al., 1986). On the other hand, the decline in production may be attributed to the reduction in the number of tuber. $\mathrm{m}^{-2}$ caused by the deep shade, which has given rise to the sink-size. 'Yushu-2' is a sweet potato cultivar that has stronger shade-tolerance than other candidates, which is affected to the least extent.

\section{Photosynthesis and chlorophyll fluorescence parameters}

Though Pn follows the order of ordered of 'Nanshu-88' > 'Yushu-6' > 'Yushu-2' in single cropping, the reduction of Pn in 'Yushu-2' is lower than the other two in relay-cropping system. Plants can adapt to photosynthesis in prevailing environment within a certain range. Meanwhile, the susceptibility of photosynthesis to adverse situation varies among different categories of crops (Lin et al., 2007). It is found in this research that $\mathrm{Pn}$ increases with the the extension in maize plant-type from compact to expanded type. Compact maize is suitable for the relay-cropping with sweet potato, which has the minimum influence on photosynthesis. The variation trend of $\mathrm{Y}(\mathrm{II})$ is consistent with that of $\mathrm{Pn}$. Compared with the control (sweet potato monoculture), obvious change can be seen in fluorescence parameters concerning the PS II activity, such as Fv/Fm, Y(II), qP and NPQ under relay-cropping conditions (Table 4). The correlation of chlorophyll fluorescence parameters with fresh yield is higher than that of photosynthetic parameters (Table 5). Furthermore, utilization of light energy in sweet potato can be better understood by fluorescence parameters under relaycropping system.

Ci value does not decrease with $\mathrm{Pn}$, which is similar to the relay-cropping system of rice (Zhang et al., 2005), in which Pn is inversely proportional to $\mathrm{Ci}$. Moreover, $\mathrm{Tr}$ and $\mathrm{Gs}$ in the relay-cropping system show the same trends, which are all lower than those in the single cropping. For the same sweet potato cultivar, the more compact plant-type is associated with the lower values of $\mathrm{Pn}, \mathrm{Tr}$ and Gs. Therefore, $\mathrm{Ci}$ in this condition is the main factor restricting sweet potato development. Shade plants have a significantly lower number of stomata per unit area than that of sun plants (Onwuemet and Johnston, 2000). As a result, its number of open stomata may be lower than plant under the full sunlight (monoculture), which results in lower $\operatorname{Tr}$ of sweet potato in the relay-cropping system than that in single cropping. Photosynthetic parameters suggest that 'Yushu-2' is more suitable over 'Yushu6 ' and 'Nanshu-88' for weak light situation.

Light energy is absorbed by chlorophyll molecules. One of its three fates is to be re-emitted as light-chlorophyll fluorescence (Maxwell and Johnson, 2000). In the relaycropping system, all NPQ values in relay-cropping system are higher than those in single cropping. Shade-tolerant plants exhibit a higher proportion of sustained photo-inhibitory NPQ (Maxwell ad Johnson, 2000). Meanwhile, plants in the relay-cropping system have a lower value of $\mathrm{qP}$, which indicates inactive PSII (Maxwell and Johnson, 2000). The opening degree of photosynthetic system II (PS II) of 'Yushu-2' (Yushu2 ) is higher than that of the other cultivars in relay-cropping system ( $\mathrm{qP}$ value of $\mathrm{AlB} 3$ is the highest). But its thermal dissipation level $(\mathrm{NPQ}=0.862)$ is lower than that of other relay-cropping collocations. These results indicate fewer influences on $\mathrm{Fv} / \mathrm{Fm}$ level for sweet potato under relaycropping conditions. But it decreases with expansion of planttype. Extended maize has great impact on $\mathrm{Fv} / \mathrm{Fm}$ values, which may be due to the small intrinsic difference between cultivars. Reports regarding Fv/Fm in Ginkgo and Fagus (Sarijeva et al., 2007) also display that it is greater in sun leaf than in shade leaf; moreover, $\mathrm{Fv} / \mathrm{Fm}$ is also affected by water-deficit (Yooyongwech et al., 2013) and drought stress (Ogren, 1990). Well watering leads to higher $\mathrm{Fv} / \mathrm{Fm}$ than water-deficit; as a result, we speculate that the potential quantum efficiency of PSII is negative in adverse situation. But it is not identical under different situations (Khan et al., 2000; Marchiol et al., 1992; Ohashi et al., 2006). Although ETR of sweet potato is also affected by maize (which is $9-10 \%$ lower than that of single cropping of sweet potato), the differences among all treatments are not noteworthy (Table 4). This is similar with the effect of photon flux density on ETR in different tissues of tomato leaf (Hetherington et al., 1998).

\section{The key enzyme of photochemical reaction}

As has been stated, $\mathrm{RuBisCO}$ activity is decreased with $\mathrm{Ci}$ within limited temperature of 0 to $30^{\circ} \mathrm{C}$ (Cen and Sage, 2005). Sun is the direct source of crop light and heat. The more extended maize plant-type receives less light from the sun, which is also a reason for lower $\mathrm{RuBisCO}$ in extended maize than in compact maize, since low light can also reduce the activity of RuBisCO (Leegood, 2000; Portis, 2003). Sucrose is the primary form of photosynthate transport, and Sucrosephosphate synthase (SPS) is a primary regulator of the sSuc synthesis rate in leaves (Babb and Haigler, 2001; Huber and Huber, 1996). In fact, SPS also plays a key role in carbon partitioning (Worrell et al., 1991; Huber and Huber, 1992). Sucrose in cell is mainly associated with two fates (Lincoln et al. 2015), which are to supply for the growth of parts like tuber, root and stem, and to be stored into carbohydrates (Starch $e t$ al.). It is possible that sweet potato in relay-cropping system distribute more sucrose to support plant growth (shoot and root dry matter ratio $(S / R)$ of relay-cropping is 2.7 ; however, that of monoculture is 0.51 on the $70^{\text {th }}$ day after sweet potato is planted), even though they have higher SPS activity than monoculture. Different sweet potato cultivars have the same behavior when relay-cropping with the same maize plant-type. 


\section{Further research plan}

It should be noted that this study mainly examines the parameters about photosynthesis, but not the genotypedependent difference. Furthermore, it lacks the comparison of interactions in underground part between root systems of sweet potato and maize. Therefore, this may be our next research emphasis.

\section{Conclusions}

Compact maize cultivar 'Zhendan-958' has smaller shading area, which is more suitable for relay-cropping with sweet potato 'Yushu-2'. Relay-cropping can significantly affect NPQ and $\mathrm{Y}(\mathrm{II})$ of sweet potato compared with the monocultures; meanwhile, it can cause reduction in yield of sweet potato. Tuber yield of 'Yushu-2' in relay-cropping is not the highest, but it has the strongest shade-tolerance. The yield reduction rate of 'Yushu-2' caused by relay-cropping is the lowest among the three cultivars. Therefore, sweet potato cultivar that has low value of NPQ and high Y (II) should be chosen. The difference in shade-tolerance of sweet potatoes should be taken into consideration in practice. Particularly, the yield of sweet potato is almost the same as each other. Compact-type maize cultivar is more beneficial to composite production, which contributes to creating better light condition for the growth of sweet potatoes.

\section{Acknowledgements}

This work was supported by the Tuber Crops Research Institute, Southwest University (China) under Grant 'Development and demonstration of high efficiency cultivation techniques of new sweet potato varieties (CSTC2016shmszx 80016)' and 'Potato high technology innovation integration demonstration (CSTC2015shms-ztzx80001)'.

\section{References}

Aladesanwa RD, Adigun AW (2008). Evaluation of sweet potato (Ipomoea batatas L.) live mulch at different spacings for weed suppression and yield response of maize (Zea mays L.) in southwestern Nigeria. Crop Protection 27(6):968-975.

Babb VM, Haigler CH (2001). Sucrose phosphate synthase activity rises in correlation with high-rate cellulose synthesis in three heterotrophic systems. Plant Physiology 127(3):1234-1242.

Bedoussac L, Justes E (2010). Dynamic analysis of competition and complementarity for light and $\mathrm{N}$ use to understand the yield and the protein content of a durum wheat-winter pea intercrop. Plant and Soil 330:37-54.

Bowes G, Ogren WL, Hageman RH (1972). Light saturation, photosynthesis rate, RuDP carboxylase activity, and specific leaf weight in soybeans grown under different light intensities. Crop Science 12(1):77-79.

Caemmerer SV, Farquhar GD. (1981). Some relationships between the biochemistry of photosynthesis and the gas exchange of leaves. Planta 153:376-387.

Cen $Y$, Sage $\mathrm{R}$ (2005). The regulation of Rubisco activity in response to variation in temperature and atmospheric $\mathrm{CO}_{2}$ partial pressure in sweet potato. Plant Physiology 139(2):979-990.
Chipungahelo GS, Ngereza A, Kawamala P, Kwileka T (2007). Effects of light regimes on different crops, sweet potato (Ipomoea batatas L.), cowpea (Vigna unguiculata L.) and pineapple (Ananas comosus L.). African Crop Science Conference Proceedings 8:467-471.

Edossa E, Nigussie D, Tena A, Yibekal A, Lemma D (2014). Growth and physiological response of tomato to various irrigation regimes and integrated nutrient management practices. African Journal of Agricultural Research 9(19):1484-1494.

Farquhar GD, Caemmerer SV, Berry JA (2001). Models of photosynthesis. Plant Physiology 125(1):42-45.

Gebru H (2015). A Review on the Comparative Advantage of Intercropping Systems. Journal of Biology, Agriculture and Healthcare 5(9):28-38.

Genty B, Briantais JM, Baker NR (1989). The relationship between the quantum yield of photosynthetic electron transport and quenching of chlorophyll fluorescence. Biochimica et Biophysica Acta 990(1):8792.

Ghanbari A, Dahmardeh M, Siahsar BA, Ramroudi M (2010). Effect of maize (Zea mays L .) - cowpea (Vigna unguiculata L.) intercropping on light distribution, soil temperature and soil moisture in arid environment. Journal of Food, Agriculture and Environment 8(1):102-108.

Ghosh PK, Ramesh P, Bandyopadhyay KK, Tripathi AK, Hati KM, Misra AK, Acharya CL (2004). Comparative effectiveness of cattle manure, poultry manure, phosphocompost and fertilizer-NPK on three cropping systems in vertisols of semi-arid tropics. I. Crop yields and system performance. Bioresource Technology 95(1):77-83.

Gliessman SR (1985). Agro:Ecological Processes in Sustainable Agriculture. Sleeping Bear Press, Chelsea, ML, USA.

Hetherington SE, Smillie RM, Davies WJ (1998). Photosynthetic activities of vegetative and fruiting tissues of tomato. Journal of Experimental Botany 49(324):1173-1181.

Huber SC, Huber JL (1992). Role of Sucrose-Phosphate Synthase in Sucrose Metabolism in Leaves. Plant Physiology 99(1992):12751278.

Huber SC, Huber JL (1996). Role and Regulation of Sucrose-Phosphate Synthase in Higher Plants. Annual Review of Plant Physiology and Plant Molecular Biology 47(1):431-444.

Islam MN, Akhteruzzaman M, Alom MS, Salim M (2014). Hybrid maize and sweet potato intercropping: a technology to increase productivity and profitability for poor hill farmers in Bangladesh. Saarc Journal of Agriculture 12(2):101-111.

Khan SR, Rose R, Haase DL, Sabin TE (2000). Effects of shade on morphology, chlorophyll concentration, and chlorophyll fluorescence of four Pacific Northwest conifer species. New Forests 19:171-186.

Kolman P (1993). Sustainable agriculture and the environment in the humid tropics. In: Richard R, HarwoodC (Eds). National Academy Press, Washington, DC pp 702.

Kriedemann PE (1968). Photosynthesis in vine leaves as a function of light intensity, temperature, and leaf age. CSIRO Division of Horticultural Research 7:213-220.

Leegood RC, Sharkey TD, Caemmerer S (2000). Photosynthesis: Physiology and Metabolism. Kluwer Academic Publishers Press, Dordrecht, Netherlands pp 85-113. 
254

Leuning R (1995). A critical appraisal of a combined stomatalphotosynthesis model for C3 plants. Plant, Cell and Environment 18(4):339-355.

Lin KH, Hwang WC, Lo HF (2007). Chilling stress and chilling tolerance of sweet potato as sensed by chlorophyll fluorescence. Photosynthetica 45(4):628-632.

Lincoln T, Eduardo Z (2015). Plant Physiology. The University of Chicago Press (4thed), Chicago.

Marchiol L, Miceli F, Pinosa M,Zerbi G (1992). Intercropping of soybean and maize for silage in northern Italy: effect of nitrogen level and plant density on growth, yield and protein content. European Journal of Agronomy 1(3):207-211.

Maxwell K, Johnson G (2000). Chlorophyll fluorescence - a practical guide. Journal of Experimental Botany 51(345):659-668.

Midmore DJ, Berrios D, Roca J (1988). Potato (Solanum spp.) in the hot tropics V. Intercropping with maize and the influence of shade on tuber yields. Field Crops Research 18(2-3):159-176.

Nedunchezhiyan M, Byju G, Jata SK (2012). Sweet Potato Agronomy. Fruit, Vegetable, and Cereal Science and Biotechnology 6(1):1-10.

Nedunchezhiyan M, Byju G, Naskar SK (2007). Sweet potato (Ipomoea batatas $L$.) as an intercrop in a coconut plantation: Growth, yield and quality.Journal of Root Crops 33(1):26-29.

Nikolopoulos D, Liakopoulos G, Drossopoulos I, Karabourniotis G (2002). The Relationship between Anatomy and Photosynthetic Performance of Heterobaric Leaves. Plant Physiology 129(1):235-243.

Njoku SC, Muoneke CO, Okpara DA, Agbo FMO (2007). Effect of intercropping varieties of sweet potato and okra in an ultisol of southeastern Nigeria. African Journal of Biomedical Research 6(14):1650-1654.

Ogren E (1990). Evaluation of chlorophyll fluorescence as a probe for drought stress in willow leaves. Plant Physiology 93(4):1280-1285.

Ohashi Y, Nakayama N, Saneoka H, Fujita K (2006). Effects of drought stress on photosyntheticgas exchange, chlorophyll fluorescence and stem diameter of soybean plants. Biologia Plantarum 50(1):138-141.

Olasantan FO, Ezumah HC, Lucas EO (1996). Effects of intercropping with maize on the micro-environment, growth and yield of cassava. Agriculture, Ecosystems and Environment 57(2-3):149-158.

Onwuemet IC, Johnston M (2000). Influence of shade on stomatal density, leaf size and other leaf characteristics in the major tropical root crops, tannia, sweet potato, yam, cassava and taro. Experimental Agriculture 36(4):509-516.

Oswald A, Alkamper J, Midmore DJ (1994). The effect of different shade levels on growth and tuber yield of sweet potato: I: Plant development. Journal of Agronomy and CropScience 173(1):41-52.

Oswald A, Alkamper J, Midmore DJ (1995). The effect of different shade levels on growth and tuber yield of sweet potato: II. Tuber yield. Journal of Agronomy and CropScience 175(175):29-40.

Portis AR (2003). Rubisco activase-Rubisco's catalytic chaperone. Photosynthesis Research 75:11-27.

Roberts NLB, Ferguson TU, Wilson LA (1986). Responses of four sweet potato cultivars to levels of shade. Dry matter production, shoot morphology and leaf anatomy. Tropical Agriculture 63(4):258-264.
Sarijeva G, Knapp M, Lichtenthaler HK (2007). Differences in photosynthetic activity, chlorophyll and carotenoid levels, and in chlorophyll fluorescence parameters in green sun and shade leaves of Ginkgo and Fagus. Journal of Plant Physiology 164(7):950:955.

Sivakumar, MVK (1993). Growth and yield of millet and cowpea in relay and intercrop systems in the Sahelian zone in years when the onset of the rainy season is early 29(1993):417-427.

Skelton LE, Barrett GW (2005). A comparison of conventional and alternative agroecosystems using alfalfa (Medicago sativa) and winter wheat (Triticum aestivum). Renewable Agriculture and Food Systems 20(1):38-47.

Szumigalski AR, Van Acker RC ( 2008). Intercropping: Land equivalent ratios, light interception, and water use in annual intercrops in the presence or absence of in-crop herbicides. American Agronomy Journal 100:1145-1154.

Terry KL (1986). Photosynthesis in modulated light: quantitative dependence of photosynthetic enhancement on flashing rate. Biotechnology and Bioengineering 28(7):988-995.

Tolera A (2003). Effects nitrogen, phosphorus farmyard manure and population of climbing bean on the performance of maize (Zea mays L.) / climbing bean (Phaseolus vulgaris L.) intercropping system in Alfisols of Bako. MSc Dissertation, Alemaya University.

Trenbath BR (1986). Resource use by intercrops. In: Francis CA (Ed). Multiple Cropping Systems. Macmillan Publishing Company Press, New York, USA pp 57-81.

Wahla IH, Ahmad R, Ehsanullah, Ahmad A, Jabbar A (2009). Competitive Functions of Components Crops in Some Barley Based Intercropping Systems. International Journal of Agriculture and Biology 11(1):69-72.

Wang CL, Guo QS., Zhu ZB, Cheng BX (2017). Physiological characteristics, dry matter, and active component accumulation patterns of changium smyrnioides in response to a light intensity gradient. Pharmaceutical Biology 55(1):581-589.

Wells AT, Chan KY, Cornish PS (2000). Comparison of conventional and alternative vegetable farming systems on the properties of a yellow earth in New South Wales. Agriculture, Ecosystems and Environment 80(12): 47-60.

Worrell AC, Bruneau JM, Summerfelt K (1991). Expression of a maize sucrose phosphate synthase in tomato alters leaf carbohydrate partitioning. Plant Cell 3(10):1121-1130.

Yooyongwech S, Theerawitaya C, Samphumphuang T, Cha-Um S (2013). Water-deficit tolerant identification in sweet potato genotypes (Ipomoea batatas L.) in vegetative developmental stage using multivariate physiological indices. Scientia Horticulturae 162:242-251.

Zhang DY, Wang X. H., Chen Y, Xu DQ (2005). Determinant of photosynthetic capacity in rice leaves under ambient air conditions. Photosynthetica 43(2):273-276.

Zheng YJ, Yang YQ, Liang SS, YI XF (2008). Effect of Methanol on Photosynthesis and Chlorophyll Fluorescence of Flag Leaves of Winter Wheat. Agricultural Sciences in China 7(4):432-437. 